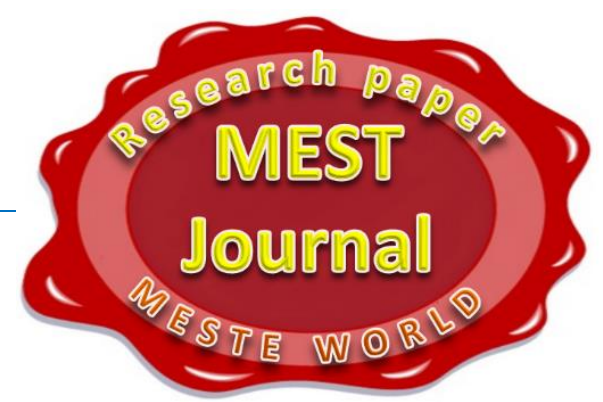

\title{
MAYOR IN THE LOCAL SELF- GOVERNMENT IN SLOVAKIA AND ELECTORAL TRENDS AND CHARACTERISTICS
}

\section{Eliska Zupova}

\author{
Pavol Jozef Safarik University in Kosice, Kosice, Slovak Republic
}

CMESTE

JEL Category: H70, Z18

\begin{abstract}
The aim of contribution is to present the partial nationwide research results aimed at detecting the electoral trend and electoral characteristics of the status of the local self-government in Slovakia. The research results were processed by using the primary data analysis and with using descriptive statistical methods. The sample consisted of a core set of objects. There had been addressed all mayors of 2,753 municipalities in the Slovak Republic. Research sample were mayors of the Slovak Republic. The results of the research brought a real reflection of the self-governing society in the municipalities of Slovakia, its electoral trend, and electoral characteristics. The distribution of the sample by gender is in favor of men (67.6\%), the highest number of respondents has a university education (51.5\%). The contribution brings recommendations for the next parliamentary term. Elections to municipalities will be held in November 2018. Compared to the previous parliamentary term, the educational level of the mayors of municipalities has increased, but the problems of municipalities in Slovakia persist. The apparent increase in education is not a determinant of the success of the mayor of the municipality in the performance of the function, it is necessary to address the compliance of the education and the requirements for the performance of the function.
\end{abstract}

Keywords: elections, public sector, local search

\section{INTRODUCTION}

Public administration is defined as administrating the public affairs, in the public interest, carried out by the state administration and local selfgovernment as its duty. Public administration is a

Address of the author:

Eliška Župová

莑”゙ eliska.zupova@upjs.sk form of public power. The State Administration is the executive, ordaining and subordinate activity carried out by the State through its authorities. Local self-government is a separate type of organizing state activity that is carried out by a different state but a state-approved entity. It is a self-contained, free self-administration.

Local self-government in Slovakia is carried out on two levels, namely by municipalities and higher 
territorial units. Nowadays, there are 2751 municipalities and 140 cities (as of 1.1.2016 . source: Statistical Office of the Slovak Republic). At the head of the municipality is the municipal mayor elected by the municipal citizens for a fouryear term of office.

\section{MAYOR IN THE MUNICIPALITY IN THE SLOVAK REPUBLIC IN CONTEXT OF EUROPEAN DEMOCRATIC THE EUROPEAN DEMOCRATIC AREA}

The mayor of the municipality is an elected local government official, who is expected to be willing and professional to work for the development of the municipality as well as the needs and interests of its citizens. (Palus \&Hencovska 2013)

European Charter of Local Self-Government is a basic right of European standards of local government. Principles reflected in the Charter apply to all kinds of local communities, which in a Contracting State exist (Kuklis \&Virova, 2012) According to the European Charter of Local SelfGovernment, local self-government is a naturallaw institute that is the expression or manifestation of the right and ability of the population to manage that part of public affairs that is their own. Conditions of local level performance are laid down in Art.7 of European Charter of Local SelfGovernment. It follows the free exercise of the functions of local elected representatives,

Mayor as one of the authorities of the Municipality is regulated in Act. No. 460/1992 Coll. Constitution of the Slovak Republic in Art. 69, which expresses "that the Mayor is elected by the inhabitants of the Municipality, who have a permanent residence in this territory on the basis of universal, equal and direct suffrage by a secret vote in a four-year term. Mayor is the executive body of the Municipality; administers the community and represents the Municipality externally".

The indirect municipal mayor's choice is in the Czech Republic, where the mayor is elected by the municipal council. Likewise, in Sweden, the general council elects its president - and he is also the mayor of the municipality. Btw, reflections on the change of legislation on the indirect election of the mayor have also taken place in the Slovak Republic. In the Netherlands, for example, to the post of Mayor "burgemeester" of municipality announced a selection procedure, which is written by the general council. (Konecny, 2016) In England, for example, representative municipalities are not formed at all in small municipalities. All inhabitants of the self-governing unit are part of the assembly of self-governing bodies. (Zajicek, 2008)

The position of mayor is regulated by $\S 13$ of Act no. 369/1990 Coll. about the general establishment. According to par. 1, the mayor is the representative of the municipality and the highest executive body of the municipality. The activity of the mayor is regulated in par. 4, section 13 - the mayor convenes and conducts meetings of the General Council and the General Council, performs general administration, represents the municipality in relation to state bodies, legal and natural persons, issues the working order, the organizational order of the general office and the order of remuneration of the employees of the municipality, informs the general council about issues and changes of the organizational order of the General Office, decides in all matters of municipal administration that are not the law or the statute of the municipality reserved to the General Council. According to par. 5 of this provision, the mayor is the statutory body of the municipality and decides on the rights, the protected interests or the obligations of natural persons and legal entities in the field of public administration. The mayor may suspend the execution of a resolution of the General Council if it considers that it is contrary to the law or is manifestly disadvantageous to the municipality. However, it is merely a resolution, not a generally binding regulation. In Spain, in municipalities with has less than 100 inhabitants, the council is not elected, but the mayor is directly elected and the municipality is directing the instruments of direct democracy. Decision-making on important issues takes place directly at the people's meeting. Generally, binding regulations called „bandos" are issued only by the mayor. It dominates its position as the highest representative of the municipality. (Palus, 2002)

The mandate of the Mayor consists of two sides: the representative one, which indicates that the Mayor may not be in conflict not only with the 
interests of the community, but do not even get into conflict with the objectives of the State in relation to the territory of the Slovak Republic, its people and territorial structure of the State (Gaspar, 1998). The other side expresses the Mayor keeping in mind the interests of the Municipality and its citizens must fulfill the essence of Local Self Government and its concept as an administrative unit. (Palus \& Hencovska, 2012)

The terms of elections for the mayor's office are regulated by $\S 165$ of Act no. 180/2014 on the conditions for the exercise of the right to vote and expresses that the mayor of the municipality may be elected voter who has no barriers to the exercise of the right to vote, has a permanent residence in the municipality in which he is a candidate and has reached the age of 25 years (in Austria active and passive voting right is already at the age of 18 and the condition of permanent residence can be abolished by the federal state).

The same way of creating a mayor's function as in the Slovak Republic, i. a direct election by citizens, is also in the federal state of Germany, BadenWuerttemberg (included in the South German model of the organization of municipal selfgovernment). The State of Baden-Wuerttemberg states in Article 72 that "people living in municipalities and districts must have representatives of their elected representatives in general, direct, free, equal and secret elections" (Grundgesetz Baden-Wuerttemberg, 1950).

The mayor's position in the State of BadenWuerttemberg is governed by the General Rule of the Gemeindeordnung in $\$ 42-\$ 51$ (Gemeindeordnung 2000). The head of the municipal administration is the mayor who is elected by the citizens of the village for eight years. The second mayor is his assistant; in smaller villages, this role can be fulfilled by the deputies appointed by the municipal council. In the Slovak Republic, the equivalent of this institution is the so- the deputy mayor, who in writing appoints the mayor from the council of deputies (§13b of Act No. 369/1990 Coll. on the general establishment)

The Legislative Requirements for the performance of the Mayor's function are defined by the law as in the case of the Slovak Republic. The mayor of the municipality must have a permanent residence in the Land of Germany and 25 years at the time of the elections. However, the law also defines the upper age limit and is 65 years old. An interesting legislative requirement is that the mayor "must provide certainty in defending the principles of free democracy" in the sense of the Basic Law of the Federal Republic of Germany (Grundgesetz fuer die Bundesrepublik Deutschland 1949). However, the law no longer indicates how the mayor must demonstrate this certainty.

Legislation in Germany does not limit the qualification that the candidate should fulfill to the function of the mayor. However, a pre-election survey shows that the mayor's post comes mainly from a public servant or active member of a local political party. (Wer wird gewaehlt? 2014)

Act no. 253/1994 Coll. on the legal status and salary of mayors of municipalities and mayors of towns and cities in $\S 2$ says that the function of the mayor of the municipality is a public function which is not performed in the employment relationship, ie there is no working relationship between the elected mayor and the municipality. Therefore, the mayor does not have a summary of the duties he has to carry out. Its position is characteristic of the performance of the function. According to $\$ 13$ par. (1) of the Act on General Settlement, the execution of the duties of the mayor is considered to be a public function. This is closely connected with $\S 139$ and $\S 128$ par. 1 of Act no. 300/2005 Coll. The Criminal Code, where the mayor is defined as a public official, is in the position of an elected municipal official who is involved in the performance of the duties of the state and of society and uses the authority entrusted to him by law.

Despite the fact, however, that the mayor does not establish an employment relationship with the municipality, but his work defines the roles he performs daily in the performance of his duties. It is important for the mayor to achieve a high level of quality work performance. Achieving an optimal level requires a positive relationship to work as a determinant of job performance.

Public administration in Slovakia has undergone many reforms, transformation and modernization changes since 1989. The decentralization of public administration and the transfer of competences to self-governing units brought significant changes in the management and financing of municipalities in the conditions of the 
Slovak Republic. These changes have brought about problems that both the layman and the professional public are discussing. The powers of the mayor are closely linked to the powers of the general counsel, but the law has not sufficiently defined them (eg the imperfectness of the statute of the mayor of the municipality). The transfer of competencies from the state is financed by the state, but the fundamental problem of their implementation is not solved. The state has transferred more than 200 powers to the municipality without undertaking serious research on whether the municipality is able to provide these competencies. Municipalities have so many competencies transferred that they do not want to secure the performance of their own, original competencies. The capacities are set as well for the municipality with 100 inhabitants as well as for the municipality with 100000 inhabitants.

Austria has a modified competence exercise in the sense that if the municipality fails to secure the exercise of competence, the state will secure compensation. In Hungary, competencies are divided in terms of population. (Konecny, 2016)

Another major problem is the ability of the municipality to implement these competencies both financially and personally. Democracy is built much higher in our country than expertise in elected offices in our case, the mayor of the municipality. The legislation does not consider whether the mayor is competent to deal with the administration of the municipality, manage the municipality, and manage the lawful matters.

In connection with the pondering of the mayor as an elected representative of the public authorities in municipalities, the function of the municipal selfgovernment and the local state administration, as in France, where the mayor has a very strong position - "wearing a double cap" - is at the highest level representatives of local government and local government. He is also known as the general monarch and the local baron.

As stated by Palus \& Hencovska (2013), the requirement for compliance of democracy and expertise is manifested in all spheres of selfgovernment, which manifests most clearly at the level of the municipal self-government as the mayor of the municipality.

On the basis of the above, it is clear that the mayor has a lot of powers and a wide range of duties, so we believe that a suitable candidate should be elected as a candidate who has not only personality prerequisites but also managerial skills, social and professional competence to perform such function and with a positive relationship to the performed function.

\section{RESEARCH}

The aim of contribution is to present the partial nationwide research results aimed at detecting the electoral trend and electoral characteristics of the status of the local self-government in Slovakia.

The research file was the basic set of objects. According to the Statistical Office of the Slovak Republic 31 January 2015 in the territory of the Slovak Republic 2753 municipalities (to 1.1.2016 there are 2751, the two municipalities have acquired the status of the city). The municipal elections took place in the Slovak Republic on 15.11.2014. The addresses were addressed by the mayors of all 2753 municipalities in the territory of the Slovak Republic.

Respondents from the research (the research sample) were mayors of the municipalities of the Slovak Republic. The respondent was sent a questionnaire electronically due to financial and time-lag. Data collection was conducted in two rounds to obtain a larger number of respondents, from October to December 2015. The data acquisition method was secured by IT specialists. From 3.11.2015 to 10.11 .2015 , the first round of addressing the mayors was carried out. In the first round, 469 respondents answered, but 456 respondents agreed with the survey. From November 30, 2015, to December 7, 2015, a second round of addressing mayors was carried out. In the second round responded 346 respondents, but 331 respondents agreed with the survey. Altogether 8,209 emails were sent to 2753 municipalities in the territory of the Slovak Republic. Each of 2753 municipalities was sent at least 1 email.

A total of 815 respondents responded to 23.12.2015, but 787 respondents agreed with the survey, representing $28.5 \%$ return. Each respondent filled in all the questionnaire entries. In the opening text, respondents were informed of the research intention, anonymity, and request for consent to participate in the research. 
The research sample is described according to established socio-demographic characteristics (gender, age, education, size of the municipality, the term of office) in Table 1.

Table 1. Sample structure by socio-demographic indicators

\begin{tabular}{|c|c|c|c|}
\hline \multicolumn{2}{|c|}{$\begin{array}{l}\text { Socio-demographic } \\
\text { indicators }\end{array}$} & $\mathbf{n}$ & $\%$ \\
\hline \multirow{3}{*}{ gender } & man & 532 & 67.6 \\
\hline & woman & 255 & 32.4 \\
\hline & together & 787 & 100 \\
\hline \multirow{5}{*}{ education } & primary school & 1 & 0.1 \\
\hline & $\begin{array}{l}\text { a secondary } \\
\text { school without } \\
\text { the final exam }\end{array}$ & 47 & 6.0 \\
\hline & $\begin{array}{l}\text { secondary school } \\
\text { with final exam }\end{array}$ & 334 & 42.4 \\
\hline & university & 405 & 51.5 \\
\hline & together & 787 & 100 \\
\hline \multirow{10}{*}{ age } & $26-31$ & 26 & 3.4 \\
\hline & $32-37$ & 55 & 6.9 \\
\hline & $38-43$ & 127 & 16.3 \\
\hline & $44-49$ & 144 & 18.4 \\
\hline & $50-55$ & 224 & 28.5 \\
\hline & $56-61$ & 169 & 21.3 \\
\hline & $62-67$ & 34 & 4.3 \\
\hline & $68-73$ & 6 & 0.7 \\
\hline & $74-79$ & 2 & 0.2 \\
\hline & together & 787 & 100 \\
\hline \multirow{7}{*}{$\begin{array}{l}\text { size of the } \\
\text { municipality }\end{array}$} & to 40 inhb. & 6 & 0.8 \\
\hline & $\begin{array}{l}\text { from } 41 \text { to } 500 \\
\text { inhb. }\end{array}$ & 318 & 40.4 \\
\hline & $\begin{array}{l}\text { from } 501 \text { to } 1000 \\
\text { inhb. }\end{array}$ & 224 & 28.5 \\
\hline & $\begin{array}{l}\text { from } 1001 \text { to } \\
3000 \text { inhb. }\end{array}$ & 206 & 26.2 \\
\hline & $\begin{array}{l}\text { from } 3001 \text { to } \\
5000 \text { inhb. }\end{array}$ & 26 & 3.3 \\
\hline & $\begin{array}{ll}\text { from } 5001 & \text { to } \\
10000 \text { inhb. }\end{array}$ & 7 & 0.9 \\
\hline & together & 787 & 100 \\
\hline \multirow{4}{*}{$\begin{array}{l}\text { term of } \\
\text { office }\end{array}$} & first & 217 & 27.6 \\
\hline & second & 236 & 30.0 \\
\hline & third and more & 334 & 42.4 \\
\hline & together & 787 & 100 \\
\hline
\end{tabular}

The distribution of the sample by gender is in favor of men $(67.6 \%)$. Only a third $(32.4 \%)$ of all mayors are female mayors (the low representation of women in political positions is for example in Italy). This fact is confirmed by the Hofstede model of cultural values (2011, In: Jelenova, 2014). The author puts Slovakia among the masculine of the society where the elected political functions are predominantly men. According to gender stereotypes in society, women do not have a policy role and hold office functions, and they have a duty to care for them. In France, on the list of candidates for elections to local authorities, the difference between male and female candidates must have only one number.

The highest number of respondents has a university education $(51.5 \%)$, followed by those who have completed secondary education $(42.4 \%)$. The share of respondents who did not graduate, respectively. only primary schools were 48 mayors $(6.8 \%)$ of the total number of respondents. From the "height" of education, it can be assumed that municipalities represent educated mayors. The public debate on the topic of "non-educated" mayors is unjustified, as well as efforts to legislate on the minimum educational requirements for serving as Mayor of the municipality as early as 2014. The identified problem is not the education of mayors but the professional competence of the mayors to perform the function.

This is the consistency between the competence of the individual - the holder of the function and the requirements for the performance of the mayor's function. The degree and extent of training has not been identified, but it is clear from the results that the mayors are educated but not capable of performing the function, as municipalities have identified serious shortcomings - the financial side of the municipality and the deficient budget management, the deficiencies in the project area, the inability to fulfill the original or transferred competencies, the disadvantageous sales and rent of property and others. In state employment offices and in the performance of work in the public interest, the selection procedure also means the ability to work, the choice of the mayor of the municipality is not possible. This leads to the fact that in the public administration we can "employ educated and choose the non-educated." The 
current situation leads to the need to create such a state in the municipal self-government when the professional competence will be the basis for the performance of the function of the mayor of the municipality.

The mayor of the municipality can be considered a manager. The type of education has not been identified, therefore the quality of managerial skills and skills cannot be expressed.

Most respondents/mayors have experience with performing this feature. The mayor of the municipality has more than 3 mandate periods of 334 respondents $(42.4 \%)$. In the second term of office, there are 206 mayors (30.0\%). According to Rudy's research (1997), one of the reasons for being a manager is, in addition to financial reasons and social status, a desire to have power. The mayor of the municipality has the authority that comes from the position of mayor as the highest representative of the self-governing unit. The reason for remaining as mayor of the municipality can be loyalty to the municipality and citizens, the effort to ensure public well-being, etc., but also the desire to influence the employees of the general office, the deputies of the general counsel to achieve their own goals, but they can also be financial reasons.

Respondents were divided into nine groups based on their age. The mean age is 49.5 years (standard deviation of 8.84) with a median age of 51 years. The youngest respondent reached 26 years and the oldest 79 was. In terms of age, most mayors involved in research ( $\mathrm{n} 427.54 \%$ ) are aged 50 to 67 years old. Most respondents ( $\mathrm{n} 224 ; 28 \%$ ) are aged 50 to 55 . Only 26 mayors (3.4\%) reached the age of 26-31, which was the lowest age category. These findings can be interpreted in several respects. The higher age of most mayors (over 50) suggests longer, respectively wealthier living and working experience, proven work results, but also wider interpersonal relationships, which could increase their credibility in the eyes of citizens in the elections. On the other hand, a low number of young mayors may also indicate the young people's lack of choice or reluctance to assume responsibility for the municipality.

Of the total number of municipalities involved in research ( $n 787$ ), 318 are in the category of up to 500 inhabitants $(40.4 \%)$ and in the category of up to 1000 inhabitants, there are 548 municipalities (69.7). Such distribution in the sample is consistent with the character of the settlement structure. The Slovak Republic is one of the countries with fragmented settlement structure. Two thirds, 775 municipalities $(67.4 \%)$ of the total number of municipalities in Slovakia constitute small municipalities (up to 1000 inhabitants) and together they comprise only $16 \%$ of the total population of Slovakia (547 161 inhabitants); (Sloboda, 2004).

A more detailed structure of the sample is shown in Tables 2 to 5.

Table 2 Sample structure by gender and age

\begin{tabular}{|l|l|l|l|l|}
\hline \multirow{2}{*}{$\begin{array}{l}\text { gender } \\
\text { age }\end{array}$} & \multicolumn{2}{|l|}{ men } & \multicolumn{2}{l|}{ women } \\
\cline { 2 - 5 } & $\mathbf{n}$ & $\%$ & $\mathbf{n}$ & $\%$ \\
\hline $26-31$ & 21 & 3.9 & 5 & 1.9 \\
\hline $32-37$ & 35 & 6.6 & 20 & 7.8 \\
\hline $38-43$ & 86 & 16.1 & 41 & 16.0 \\
\hline $44-49$ & 96 & 18.1 & 48 & 18.9 \\
\hline $50-55$ & 146 & 27.4 & 78 & 30.6 \\
\hline $56-61$ & 109 & 20.5 & 60 & 23.5 \\
\hline $62-67$ & 31 & 5.9 & 3 & 1.3 \\
\hline $68-73$ & 6 & 1.1 & 0 & 0.0 \\
\hline $74-79$ & 2 & 0.4 & 0 & 0.0 \\
\hline together & $\mathbf{5 3 2}$ & $\mathbf{1 0 0}$ & $\mathbf{2 5 5}$ & $\mathbf{1 0 0}$ \\
\hline
\end{tabular}

Table 3 Sample structure by gender and education

\begin{tabular}{|l|l|l|l|l|}
\hline \multirow{2}{*}{$\begin{array}{l}\text { gender } \\
\text { education }\end{array}$} & \multicolumn{2}{|l|}{ men } & \multicolumn{2}{l|}{ women } \\
\cline { 2 - 6 } $\mathbf{n}$ & $\%$ & $\mathbf{n}$ & $\%$ \\
\hline primary school & 1 & 0.2 & 0 & 0.0 \\
\hline $\begin{array}{l}\text { secondary school } \\
\text { without final exams }\end{array}$ & 44 & 8.3 & 3 & 1.1 \\
\hline $\begin{array}{l}\text { secondary school } \\
\text { with final exams }\end{array}$ & 213 & 40.0 & 122 & 47.6 \\
\hline university & 274 & 51.5 & 131 & 51.3 \\
\hline together & $\mathbf{5 3 2}$ & $\mathbf{1 0 0}$ & $\mathbf{2 5 5}$ & $\mathbf{1 0 0}$ \\
\hline
\end{tabular}


Table 4 Sample structure by education and size of the municipality

\begin{tabular}{|c|c|c|c|c|c|c|c|c|}
\hline \multirow{2}{*}{ 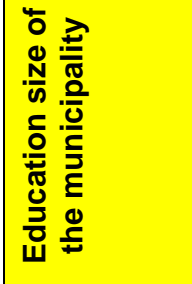 } & \multicolumn{2}{|c|}{ 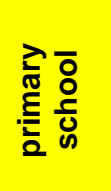 } & \multicolumn{2}{|c|}{ 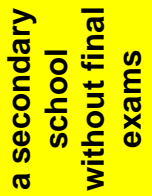 } & \multicolumn{2}{|c|}{ 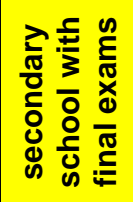 } & \multicolumn{2}{|l|}{$\begin{array}{l}\frac{2}{0} \\
\frac{20}{20} \\
\frac{2}{5}\end{array}$} \\
\hline & $\mathbf{n}$ & $\%$ & $\mathbf{n}$ & $\%$ & $\mathrm{n}$ & $\%$ & $\mathrm{n}$ & $\%$ \\
\hline to 40 inhab. & 0 & 0.0 & 1 & 2.1 & 2 & 0.6 & 3 & 0.7 \\
\hline $\begin{array}{l}\text { from } 41 \text { to } \\
500 \text { inhab. }\end{array}$ & 1 & 100 & 20 & 42.6 & 177 & 53.0 & 120 & 29.6 \\
\hline $\begin{array}{l}\text { from } 501 \text { to } \\
1000 \text { inhab. }\end{array}$ & 0 & 0.0 & 18 & 38.3 & 86 & 25.7 & 120 & 29.6 \\
\hline $\begin{array}{l}\text { from } 1001 \text { to } \\
3000 \text { inhab. }\end{array}$ & 0 & 0.0 & 8 & 17.0 & 65 & 16.0 & 133 & 32.8 \\
\hline $\begin{array}{l}\text { from } 3001 \text { to } \\
5000 \text { inhab. }\end{array}$ & 0 & 0.0 & 0 & 0.0 & 4 & 1.2 & 22 & 5.4 \\
\hline $\begin{array}{l}\text { from } 5001 \text { to } \\
10000 \text { inhab. }\end{array}$ & 0 & 0.0 & 0 & 0.0 & 0 & 0.0 & 7 & 1.7 \\
\hline together & 1 & 100 & 47 & 100 & 334 & 100 & 405 & 100 \\
\hline
\end{tabular}

Table 5 Sample structure by terms of office and size of the municipality

\begin{tabular}{|l|c|c|c|c|c|c|}
\hline terms of office & \multicolumn{2}{|c|}{ first } & \multicolumn{2}{c|}{ second } & \multicolumn{2}{c|}{$\begin{array}{l}\text { third and } \\
\text { more }\end{array}$} \\
\cline { 2 - 7 } municipality & $\mathbf{n}$ & $\%$ & $\mathbf{n}$ & $\%$ & $\mathbf{n}$ & $\%$ \\
\hline to 40 inhab. & 1 & 0.5 & 3 & 1.3 & 2 & 0.6 \\
\hline $\begin{array}{l}\text { from } 41 \text { to } \\
500 \text { inhab. }\end{array}$ & 89 & 41.0 & 93 & 39.4 & 136 & 40.8 \\
\hline $\begin{array}{l}\text { from } 501 \text { to } \\
1000 \text { inhab. }\end{array}$ & 61 & 28.1 & 64 & 27.1 & 99 & 29.6 \\
\hline $\begin{array}{l}\text { from } 1001 \text { to } \\
\text { 3000 inhab }\end{array}$ & 60 & 27.6 & 66 & 28.0 & 80 & 23.9 \\
\hline $\begin{array}{l}\text { from } 3001 \text { to } \\
5000 \text { inhab. }\end{array}$ & 5 & 2.3 & 10 & 4.2 & 11 & 3.3 \\
\hline $\begin{array}{l}\text { from } 5001 \text { to } \\
10000 \text { inhab. }\end{array}$ & 1 & 0.5 & 0 & 0.0 & 6 & 1.8 \\
\hline together & $\mathbf{2 1 7}$ & $\mathbf{1 0 0}$ & $\mathbf{2 3 6}$ & $\mathbf{1 0 0}$ & $\mathbf{3 3 4}$ & $\mathbf{1 0 0}$ \\
\hline
\end{tabular}

In the age category (Table 2) from 50-61 years, women $(54.1 \%)$ predominate over males $(47.9 \%)$. The number of mayors in the age group over 62 is more men (n 39, 7.4\%) than women (n 3, 1.3\%). There are no significant differences in younger age groups.

A higher level of education is achieved by female respondents who hold the position of the highest representative of the municipality (Table 3 ).
Secondary education without maturity ended 45 mayors $(8.5 \%)$, of which 4 were women $(1.1 \%)$.

In larger municipalities, over 1000 inhabitants, mayors $(39.9 \%)$ are predominantly educated mayors. In small villages, up to 1,000 inhabitants, secondary school graduates with completed graduation $(79.3 \%)$ predominate. In small villages, the prevalence $(82.4 \%)$ of secondary-educated mayors without maturity is also prevalent (Table 4). This result is a reflection of the Slovak society according to the results of the Statistical Office of 2014. The university educated inhabitants in the urban environment live up to twice as much as in rural areas, therefore there is a trend of the significantly higher education level of the urban population (Slovak national Statistical Office, 2014).

An interesting result is the comparison of the terms of office and the size of the municipality (Table 5). Most mayors who have more than three terms of office are in municipalities with up to 500 inhabitants. The lack of candidates for mayors from municipal elections is mainly due to small municipalities, so the performance of the function "remains in the hands" of the current mayor. But the reason may be different - eg. financial evaluation of the function. The mayor's salary is the salary which is the product of the average monthly salary of the employee in the national economy for the previous calendar year and the multiple according to Act no. 253/1994 on the legal status and salary of mayors of municipalities and mayors of towns. The average wage in the national economy for 2015 was 882 euros. The mayors are classified into nine wage groups according to the number of inhabitants of the municipality or city, and multiples are set from 1.49 times (mayor of the municipality to 500 inhabitants) to 3.58 times (mayor over 100000 inhabitants) of the average monthly wage in the national economy. For example, the minimum salary of mayor in the municipality, up to 500 inhabitants is 1314 euros. The municipal council may increase this salary by up to $70 \%$. If the municipal council approves the increase of the basic salary by up to $70 \%$, the sum of the monthly salary may be up to the municipality's mayor up to 500 inhabitants and 2234 euros. It is then clear that the costs of managing a small community make up most of its expenses because the salary 
of the municipality mayor, deputies of the general counsel and the running of the general office will absorb the entire budget.

\section{CONCLUSIONS}

The results of the research brought a real reflection of the self-governing society in the municipalities of Slovakia. The mayor of the municipality is predominantly male $(67.6 \%)$, with higher education (51.5\%); most mayors (42.4\%) are in office for more than 3 mandate periods, $54 \%$ of mayors are aged 50 to 67 , senior women have graduated, and mayors over age 62 are men. In municipalities of more than 1000 inhabitants the mayor of the municipality is a higher education college and in small municipalities, up to 1000 inhabitants, the secondary school graduates are the mayors with graduation. Most mayors who have more than three office positions are in municipalities with up to 500 inhabitants.

Compared to the results of Palus and Hencovska (2013), the education level of the mayors increased. In the electoral period from 2010 to 2014 , the predominance of the mayors of the secondary school graduates was the predominance of the university-educated mayors in the 2014-2018 term. The emerging trend is obviously a reflection of the increasing demands for the mayor's office, but it may also be a reflection of the apparently justified but unsuccessful efforts of public-political actors to impose educational requirements for the performance of the mayor's office or reflection of the number of university graduates and their need for practical application.

The last problem that has been identified is that the mayors of municipalities have the professional competence of the mayors for performance at the end of the university education. Education is still a current requirement for the performance of a function, but in terms of competence tuning (compliance with the requirements of the mayor's office and the competence of the mayor), attention should be paid to the expertise in municipal selfgovernment, which should be the basis for the mayor's function, professional competencies.

\section{WORKS CITED}

Bertelsmann Stiftung (2008). Deutscher Staedtetag, Deutscher Staedte-u. Gemeindebund, Beruf Buergermeister/in [online]. Mannheim: 2008. [cit. 2015-12-29]. Retrieved from: http://mifkjf.rlp.de/fileadmin/mehr-frauen-in-die politik/dokumente/Beruf_Buergermeisterln.pdf

Belajova, A. (2012). Dovody a podmienky pre profesionalizovanie vykonu verejnej spravy na Slovensku. In: Kvalita samospravneho manazmentu na miestnej urovni, Zbornik prispevkov z vedeckeho workshopu. Mojmirovce: Vysoka skola ekonomie a manazmentu verejnej spravy v Bratislave, Institut aplikovaneho manazmentu, pp. 9-19.

European Charter of Local Government 1985.

Gaspar, M. (1998). Spravne pravo - teoria a prax. Kosice: Univerzita Pavla Jozefa Safarika v Kosiciach, Pravnicka fakulta.

Gecikova, I. (2012). Struktura starostov/primatorov obci SR z hladiska ich pripravenosti na vykon verejnej funkcie. In: Kvalita samospravneho manazmentu na miestnej urovni, Zbornik prispevkov z vedeckeho workshopu. Mojmirovce: Vysoka skola ekonomie a manazmentu verejnej spravy v Bratislave, Institut aplikovaneho manazmentu, 20-28.

Gemeindeordnung Baden-Wuerttemberg, 24.6.2000

Grundgesetz fuer die Bundesrepublik Deutchland 23.05.1949

Grundgesetz Baden-Wuerttemberg 11.11.1950

Jelenova, I. (2014). Interkulturna komunikacia. Kosice: Univerzita P.J. Safarika v Kosiciach.

Kantorova, M. (2009). Verejny cinitel' - postavenie a trestnopravna ochrana. In: Verejna sprava a spolocnost', 1, pp. 80-86.

Konecny, S. (2016). Verejna sprava v statoch Europskej unie. Unpublished source.

Medzinarodny pakt o obcianskych pravach. (1996). 
Palus, I. (2002). Miestna sprava vo vybranych statoch EU. Kosice: Univerzita Pavla Jozefa Safarika $\checkmark$ Kosiciach, Fakulta verejnej spravy.

Palus, I. (2012). Odvolanie starostu obce ako sucast' demokracie a odbornosti v obecnej samosprave. In: Uzemna samosprava ako forma verejnej moci. Recenzovany zbornik prispevkov z vedeckej konferencie. Kosice: Univerzita Pavla Jozefa Safarika v Kosiciach, Fakulta verejnej spravy, pp. 125-132.

Palus, I., \& Hencovska, M. (2013). Vzt'ah demokracie a odbornosti v obecnej samosprave z pohl'adu starostov obci. In: Zbornik prispevkov z medzinarodnej vedeckej konferencie Teoria a prax verejnej spravy. Kosice: Univerzita Pavla Jozefa Safarika v Kosiciach, Fakulta verejnej spravy, pp. 260-267.

Palus, I., \& Hencovska, M. (2013). Starosta obce ako organ verejnej moci. In: Viazanost' verejnej spravy pravom, Zbornik vedeckych prac. Kosice: Univerzita Pavla Jozefa Safarika v Kosiciach, Fakulta verejnej spravy, pp. 30-45.

Palus, I., Jesenko, M., \& Krunkova, A. (2010). Obec ako zaklad uzemnej samospravy. Kosice: Univerzita Pavla Jozefa Safarika v Kosiciach, Fakulta verejnej spravy.

Papuncova, V. (2012). Kvalifikacne predpoklady starostu pre vykon funkcie z pohl'adu obyvatel'ov, In: Kvalita samospravneho manazmentu na miestnej urovni, Zbornik prispevkov z vedeckeho workshopu. Mojmirovce: Vysoka skola ekonomie a manazmentu verejnej spravy v Bratislave, Institut aplikovaneho manazmentu, pp. 29-36.

Rudy, J. (1997). Manazment a teoria chaosu alebo novy model organizacie. Faber, Bratislava.

Sloboda, D. (2004). Charakter sidelnej struktury Slovenska ako predpoklad pre komunalnu reformu [online]. [cit. 11.01.2016.] Retrieved from: http://www.konzervativizmus.sk/upload/prezentacie/Sloboda_komreforma.pdf

Statisticky urad Slovenskej republiky. (2014). Fakty o zmenach v zivote obyvatelov SR, pp. 103 -104.

Wer wird gewaehlt? (2014). Kommunalwahl Baden - Wuerttemberg am 25. Mai 2014. Wer wird gewaehlt? [online] [cit. 2018-01-20]. Retrieved from: http://www.kommunalwahlbw.de/wer_wird_gewaehlt_kommunalwahl.html

Zajicek, J. (2008). Mistni samospravy a manazeri mistni samospravy $v$ sedmnacti evropskych zemich. [online]. [cit. 2016-01-11]. Retrieved from: http://www.mvcr.cz/clanek/mistni-samospravy-amanazeri-mistni-samospravy-v-sedmnacti-evropskych-zemich-i.aspx

Act no. 460/1992 Coll. Constitution of the Slovak Republic as amended by later amendments and provisions.

Act no. 369/1990 Coll. the Act on General Settlement, as amended.

Act no. 253/1994 Coll. on the legal status and salary of mayors of municipalities and mayors of cities, as amended.

Act no. 180/2014 Coll. on the conditions for the exercise of the right to vote, as amended.

Received for publication: $\quad 16.01 .2018$

Revision received: $\quad 02.02 .2018$

Accepted for publication: $\quad$ 07.06.2018

\section{How to cite this article?}

Style - APA Sixth Edition:

Zupova, E. (2018, July 15). Mayor in the Local Self-government in Slovakia and Electoral Trends and Characteristics. (Z. Cekerevac, Ed.) MEST Journal, 6(2), 167-176. doi:10.12709/mest.06.06.02.20 
Style - Chicago Sixteenth Edition:

Zupova, Eliska. 2018. "Mayor in the Local Self-government in Slovakia and Electoral Trends and Characteristics." Edited by Zoran Cekerevac. MEST Journal (MESTE) 6 (2): 167-176. doi:10.12709/mest.06.06.02.20.

Style - GOST Name Sort:

Zupova Eliska Mayor in the Local Self-government in Slovakia and Electoral Trends and Characteristics [Journal] // MEST Journal / ed. Cekerevac Zoran. - Toronto : MESTE, July 15, 2018. - 2 : Vol. 6. - pp. 167-176.

Style - Harvard Anglia:

Zupova, E., 2018. Mayor in the Local Self-government in Slovakia and Electoral Trends and Characteristics. MEST Journal, 15 July, 6(2), pp. 167-176.

Style - ISO 690 Numerical Reference:

Mayor in the Local Self-government in Slovakia and Electoral Trends and Characteristics. Zupova, Eliska. [ed.] Zoran Cekerevac. 2, Toronto : MESTE, July 15, 2018, MEST Journal, Vol. 6, pp. 167-176. 